Srios I

(1758-1826)

mins.s.

\title{
V. On nævi materni
}

\section{Chirurgicus}

To cite this article: Chirurgicus (1810) V. On nævi materni , Philosophical Magazine Series 1, 35:141, 35-36, DOI: 10.1080/14786441008563014

To link to this article: http://dx.doi.org/10.1080/14786441008563014

曲 Published online: 18 May 2009.

Submit your article to this journal $\pi$

Џll Article views: 2

Q View related articles $\asymp$ 
in the same direction with different velocities; that with the greater velocity, on overtaking the other, communicates part of its force, and of course loses so much in its velocity.

\section{On Neri Materni.}

\section{To Mr. Tilloch.}

Sir, $T_{\text {he last Number of your Philosophical Magazine }}$ contains a discussion, by one of your ingenious correspondents, in support of the old prejudice that certain congenital marks or excrescences, commonly called ncevi maierni, originate from the influeuce of the mind of the parent. As the paper, no doubt, was written with a serious object, I comply with the writer's request in forwarding to you for publication some observations on the subject.

It is agreed that nevi materni resemble known objects in nothing more than form; although, as ENCEPS (the writer's signature) observes, "more than one volume has been filled with reputed instances of the effects of the mother's imagination upon her offepring." The forms, how'ever, of ncevi materni in general are so far from having a resemblance to any known object, that the experience of practitioners, who are in the daily habits of operating on some, and seeing many others, proves as much as extensive experience can prove, that the relations of navi materni resembling a bunch of grapes, or a bit of bacon, are to be classed with the idle tales of the nursery. Even Enceps himself "was for a long time prepossessed with the same notion," viz. that such fanciful forms of ncevi materni were " idle tales," till a case "was related to him by an intelligent friend who had seen a child born with only one leg, as well as its mother, who declared her firm belief that the cause of this imperfection in her child was a violent fright which she experienced from seeing a beggar suddenly uncover the wounded stump of his thigh." This, however, is not an example of naevus maternus, but of monstrosity. Now I will seriously ask Enceps, at what period of pregnancy this uniortunate mother received such a violent fright. In the latter months of prognancy, after the limbs of the foetus had been formed? The separation of a limb, and its still more extraordiuary annihilativ:1, must.then be explained as the effects of imagination, - or in the early months of pregnancy, before the ovum liad become organ- 
ized! The imagination must then be supposed to act on a part of the fotus before such a part had any existence. The common opinion is, that monstrosity depends on original conformation of the ovum; nor is it by any means inteligible that a metamorphosis or annihilation of any part of the foetus can take place from an impression on the imagination of the parent.

I have said that Enceps's object in writing was not levity; but when I came to the tale of the cat and the kittens, my suspicions were somewhat roused. "A pregnant she cat" had its tail trodden upon, and lo! when she littered she had an even number of kittens; otherwise the surprising things that did happen, could not have happened-that "half of her kittens had their tails bent in the middle!". and that half had not. The circumstance which roused my suspicion was the gravity with which Enceps says " this fact (or rather this tale) seems to be very important, and to prove nearly to a demonstration, that the imagination of pregnant females has the power of acting on the bodily conformation of their young!!"’

As a medical man, I had reason to hope that the old prejudice of the perfection of the foetus being in anywise contingent on the imagination of the parent was at an end; and having long been a reader of your respectable Magazine, I could not observe Enceps's reasoning in favour of such a prejudice, without presuming that it was subject to animadversion.

$$
\text { I remain, sir, your humble servant, }
$$

December, 1809.

Chinurgicus.

VI. Memoir on the Mineralogical Geography of the Environs of Paris. By Messrs. Cuvier and Brogniart*.

$\mathrm{T}_{\mathrm{HE}}$ country in which Paris is situated is perhaps one of the most remarkable hitherto observed, from the succession of the various soils which compose it, and from the extraordinary remains of ancient organizations which it contains : myriads of sea shells, regularly alternated with fresh-water shells, form the principal mass : bones of terrestrial animals, entirely unknown even with respect to their genera, fill certain parts : other bones of species remarkable from their size, and the counterparts of which are only

- Annales du Musekm d'Histoire Naturelle, tome xi. p. 293.

found 